\title{
Monoclonal Antibodies against the Haemolysin of Vibrio vulnificus
}

\author{
By KENJI OKADA, * MASAO MITSUYAMA, SHUNJI MIAKE AND \\ KAZUNOBU AMAKO \\ Department of Bacteriology, Faculty of Medicine, Kyushu University, Fukuoka 812, Japan
}

(Received 4 December 1986; revised 16 April 1987)

\begin{abstract}
The extracellular haemolysin produced by Vibrio vulnificus strain FCC was partially purified from the culture supernate by sequential ammonium sulphate precipitation, gel filtration with Sepharose 4B, and DEAE-Sephacel ion-exchange column chromatography. Using this semipurified haemolysin as the antigen, several monoclonal antibodies (MAbs) were established; they were all of the IgG2b class with lambda light chains. One representative MAb, 6F8D, completely neutralized the haemolytic activity and mouse lethal activity of extracellular toxin(s). In immunoblotting analysis of the peptides of the semi-purified haemolysin separated by SDSPAGE, this MAb reacted, in particular, with a $36 \mathrm{kDa}$ peptide. These findings suggest that the haemolysin is probably identical to the lethal toxin in the culture supernate of $V$. vulnificus strain FCC, which contained the $36 \mathrm{kDa}$ peptide.
\end{abstract}

\section{INTRODUCTION}

Vibrio vulnificus is a halophilic bacterium causing gastroenteritis, wound infections, meningitis, myositis, pneumonia, or septicaemia in humans. Fulminating wound infections and septicaemia are often serious and the mortality rate is high in compromised patients especially in those with a liver cirrhosis or haemochromatosis (Blake et al., 1980; Farmer, 1979; Hollis et al., 1976; Tison \& Kelly, 1984b). Putative virulence factors include extracellular cytolysin (Gray \& Kreger, 1985; Kreger \& Lockwood, 1981), phospholipase A2 (Testa et al., 1984), elastolytic protease (Kothary \& Kreger, 1985), collagenase (Smith \& Merkel, 1982), siderophores (Simpson \& Oliver, 1983) and a surface antigen conferring antiphagocytic capacity (Amako et al., 1984; Kreger et al., 1984; Yoshida et al., 1985). Pathological changes similar to those observed clinically, such as haemoconcentration, tissue necrosis or fatal septicaemia, also occur in experimental infections of animals (Bowdre et al., 1981; Poole \& Oliver, 1978).

Cytolysin or haemolysin is apparently involved in the pathogenesis of $V$. vulnificus (Gray \& Kreger, 1985, 1986). In cases of Vibrio parahaemolyticus infection, it was reported that thermostable direct haemolysin accounted for the mortality of the infected animal (Honda et al., 1976). However, it is not known whether the haemolysin of $V$. vulnificus also has such lethal activity, or whether it is involved in the development of haemoconcentration.

Monoclonal antibodies (MAbs) are useful tools for analysing various bacterial toxins (Frank \& Parker, 1984; Kamata et al., 1985; Remmers et al., 1982; Sheppard et al., 1984). As MAbs bind to a single site on an antigen molecule, they are invaluable probes for studying structurefunction relationships. In the present study, MAbs against $V$. vulnificus haemolysin were established and used to examine the relationship of the haemolysin to the lethal toxin produced by the bacterium.

Abbreviations: MAb, monoclonal antibody; MLD, minimal lethal dose; SRBC, sheep red blood cells. 


\section{METHODS}

Bacterium and culture conditions. Strain FCC of $V$. vulnificus was used (Amako et al., 1984). It was maintained on

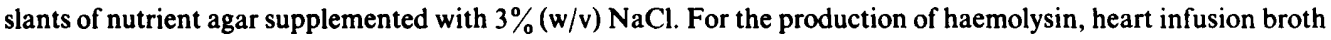
containing $0.5 \% \mathrm{NaCl}$ was used. The bacterium was cultured aerobically at $37{ }^{\circ} \mathrm{C}$ for $8 \mathrm{~h}$ in a rotary shaker running at 200 r.p.m. (NBS, type G24, New Brunswick Scientific Co.).

Preparation of haemolysin. The culture supernate was obtained by centrifugation ( $16000 \mathrm{~g}$ for $30 \mathrm{~min}$ ). Ammonium sulphate was added to the pooled culture supernate to $40 \%$ saturation $\left(0.28 \mathrm{~g} \mathrm{ml}^{-1}\right)$ and the preparation was then stirred overnight at $4{ }^{\circ} \mathrm{C}$ with a magnetic stirrer. The precipitate was recovered by centrifugation and dissolved in $10 \mathrm{~mm}$-TE buffer (10 mM-Tris/HCl, $1 \mathrm{~mm}$-EDTA, pH 7.0). The concentrated haemolysin $\left(420 \mathrm{mg}\right.$ protein $\left.\mathrm{ml}^{-1}\right)$ was applied to a column $(2.6 \times 90 \mathrm{~cm})$ of Sepharose $4 \mathrm{~B}$ gel (Pharmacia) and eluted with TE buffer at a flow rate of $15 \mathrm{ml} \mathrm{h}^{-1}$. Pooled fractions from the gel filtration were applied to a DEAESephacel column ( $1.3 \times 45 \mathrm{~cm}$, Pharmacia) equilibrated with $10 \mathrm{~mm}$-Tris/HCl buffer, pH 7.0 (Tris buffer). After washing the column with the buffer, the adsorbed proteins were eluted with a linear gradient of 0 to $0 \cdot 5 \mathrm{M}-\mathrm{NaCl}$ in Tris buffer followed by wash-out with 4 bed volumes $(240 \mathrm{ml})$ of $1 \mathrm{M}-\mathrm{NaCl}$ in Tris buffer. Fractions were assayed for absorbance at $280 \mathrm{~nm}$ and for haemolytic activity. The fractions having haemolytic activity were used as the semi-purified haemolysin antigen for immunization.

Production of MAbs. Male 6-week-old BALB/c mice were injected subcutaneously with $200 \mu \mathrm{g}$ of the semipurified haemolysin suspended in Freund's complete adjuvant. On days 7 and 14 they were re-injected with $200 \mu \mathrm{g}$ of the same antigen suspended in Freund's incomplete adjuvant. A final booster of $100 \mu \mathrm{g}$ antigen in phosphatebuffered saline $\left(8.0 \mathrm{~g} \mathrm{NaCl}^{2} .9 \mathrm{~g} \mathrm{Na}_{2} \mathrm{HPO}_{4} .12 \mathrm{H}_{2} \mathrm{O}, 0.2 \mathrm{~g} \mathrm{KCl}, 0.2 \mathrm{~g} \mathrm{KH}_{2} \mathrm{PO}_{4} \mathrm{l}^{-1}\right.$, pH 7.2; PBS) was given intravenously $3 \mathrm{~d}$ before the cell fusion. Spleen cells were obtained on day 24 and were fused with mouse myeloma P3-X63-Ag-U1 (P3U1) cells at a ratio of $10: 1$, in a solution containing $35 \%(\mathrm{v} / \mathrm{v})$ polyethylene glycol 1000 , according to the procedure described by Harn et al. (1984). Fused cells were suspended in HT medium, comprising Dulbecco's modified Eagle medium (GIBCO) supplemented with 10\% (v/v) NCTC109 (Whittaker, M. A. Bioproducts Inc.), 10\% (v/v) NUSERUM (Collaborative Research Inc.), $2.5 \mathrm{~mm}$-L-glutamine, $1 \mathrm{mm-cis-}$ oxaloacetic acid (Sigma), 0.4 mm-sodium pyruvate (Sigma), 0.16 unit bovine insulin $\mathrm{ml}^{-1}$ (Sigma), $50 \mu \mathrm{g}$ gentamicin $\mathrm{ml}^{-1}$ and $40.8 \mu \mathrm{g}$ hypoxanthine $/ 11.4 \mu \mathrm{g}$ thymidine (HT) $\mathrm{ml}^{-1}$. The cell suspension was then dispensed in 96-well tissue culture plates. HAT selection (Harn et al., 1984) was done on days 1,7 and 14 after cell fusion. Supernates of wells containing growing clones were tested on days 14 to 21 after fusion for MAbs, using enzymelinked immunosorbent assay (ELISA) and neutralization of haemolysin, as described below. The antibodyproducing celis were recloned by limiting dilution and hybridomas were injected into pristane-primed BALB/c mice. The ascites obtained from the mouse peritoneal cavity was precipitated with ammonium sulphate at $45 \%$ saturation. The precipitate was dialysed and each sample was adjusted to $10 \mathrm{ml}$ of suspension. The class and subclass of MAbs were checked using isotype or subclass-specific antisera (Zymed Laboratories) by the Mono AbID EIA kit based on ELISA.

Haemolysin assay. This was based upon the assay described by Shinoda et al. (1985). Microtitre plates of 96 wells with conical bottoms containing $50 \mu$ l of a serial doubling dilution of the preparation to be assayed and $50 \mu l$ of a $1 \%(\mathrm{v} / \mathrm{v})$ sheep red blood cell (SRBC) suspension in PBS were incubated at $37^{\circ} \mathrm{C}$ for $1 \mathrm{~h}$ and kept at $4{ }^{\circ} \mathrm{C}$ for an additional $10 \mathrm{~min}$ to allow the unlysed $\mathrm{SRBC}$ to sediment. The haemolysin titre was defined as the reciprocal of the highest dilution of haemolysin giving complete haemolysis.

Neutralization of haemolysin by $M A B$. Serially twofold-diluted hybridoma culture fluids $(50 \mu l)$ were added to 50 $\mu \mathrm{l} \mathrm{semi-purified} \mathrm{haemolysin}\left(5 \mu \mathrm{g}\right.$ protein $\left.\mathrm{ml}^{-1}\right)$. After incubation at $37^{\circ} \mathrm{C}$ for $30 \mathrm{~min}, 50 \mu \mathrm{l} 1 \%(\mathrm{v} / \mathrm{v}) \mathrm{SRBC}$ was added to the wells. The plates were incubated and stored as above. The haemolysis inhibition titre was defined as the reciprocal of the highest dilution of antibodies inhibiting haemolysis in the standard assay described above.

Neutralization of lethal activity by MAb. Neutralization assays were performed using eight to ten 5-7-week-old female ddy mice (Kyudo Experimental Animal Co.) per experimental group. Haemolysin at a dose of 1 MLD (minimal lethal dose, $100 \mu \mathrm{g}$ per mouse) or 2 MLD was incubated with MAb (6F8D) diluted 1 in 10,1 in 5 and 1 in 2 with PBS for $30 \mathrm{~min}$ at $37^{\circ} \mathrm{C} ; 0.4 \mathrm{ml}$ of the mixture was then injected intravenously into mice and the mortality was observed for $3 \mathrm{~d}$. In a passive transfer assay, mice was given intraperitoneally PBS-diluted MAb (6F8D), or P3Ul-induced normal ascites, as the control. After $30 \mathrm{~min}$, treated mice were challenged intravenously with semipurified haemolysin at a dose of 1 or 3 MLD, and mortality was observed for $3 \mathrm{~d}$.

$S D S-P A G E$. This was done by a modification of the method of Laemmli (1970). The samples to be analysed were boiled in solubilizing buffer [0.25 $\mathrm{M}$-Tris buffer, $2 \%(\mathrm{w} / \mathrm{v}) \mathrm{SDS}, 4 \%(\mathrm{v} / \mathrm{v}) 2$-mercaptoethanol, $20 \%(\mathrm{w} / \mathrm{v})$ glycerol and $0.1 \%$ bromophenol blue] for $3 \mathrm{~min}$. Electrophoresis was performed at a constant current of $20 \mathrm{~mA}$ through a $4 \%(\mathrm{w} / \mathrm{v})$ polyacrylamide stacking gel and a $12.5 \%$ slab separating gel. Protein bands were stained with $0.1 \%$ Coomassie blue $/ 25 \%(\mathrm{v} / \mathrm{v}) 2$-propanol $/ 10 \%(\mathrm{v} / \mathrm{v})$ acetic acid. In some experiments, 2-mercaptoethanol was omitted from the solubilizing buffer.

Immunoblotting procedures. After SDS-PAGE, proteins were transferred electrophoretically from the gel to nitrocellulose paper, using the method of Towbin et al. (1979). A constant potential of $30 \mathrm{~V}$ was applied to the gel- 
nitrocellulose paper sandwich for $16 \mathrm{~h}$ in an electroblot buffer $(25 \mathrm{~mm}-\mathrm{Tris} / \mathrm{HCl}, 192 \mathrm{~mm}$-glycine, $20 \%(\mathrm{v} / \mathrm{v})$ methanol; $\mathrm{pH} \mathrm{8.3).} \mathrm{The} \mathrm{transferred} \mathrm{proteins} \mathrm{were} \mathrm{stained} \mathrm{with} \mathrm{amido} \mathrm{black.} \mathrm{The} \mathrm{paper} \mathrm{was} \mathrm{washed} \mathrm{three} \mathrm{times}$ with PBS/Tween, incubated for $90 \mathrm{~min}$ at room temperature with MAb diluted in PBS/Tween, then washed three times with PBS/Tween and incubated with peroxidase-conjugated goat anti-mouse immunoglobulins (Cappel) diluted (1 in 800) with PBS/Tween. After 90 min incubation at room temperature and three washes, the blots were developed, using 4-chloro-1-naphthol as the peroxidase substrate.

\section{RESULTS}

The production of extracellular haemolysin was maximum when $V$. vulnificus FCC was cultured aerobically for 6 to $8 \mathrm{~h}$ at $37^{\circ} \mathrm{C}$ in heart infusion broth containing $0.5 \% \mathrm{NaCl}$. Therefore, this condition was generally used for preparation of the haemolysin.

Partial purification of the extracellular haemolysin. The haemolysin was concentrated 46-fold from the culture supernate by ammonium sulphate precipitation. This concentrated haemolysin was eluted from the Sepharose $4 \mathrm{~B}$ column forming two major protein peaks. The first peak, in the void volume fractions, contained slight haemolytic activity; most of the activity was recovered in the second major peak. For further purification, samples in the second major peak were applied to a DEAE-Sephacel column. Lethal activity and haemolytic activity were present in the fractions eluting at 0.25 to $0.4 \mathrm{M}-\mathrm{NaCl}$. Samples of haemolysin at each purification step were analysed by SDS-PAGE (Fig. 1). Two major bands of 36 and $20 \mathrm{kDa}$, and many faint additional bands, were evident. During this step of purification, no significant change in the profile of the major peptide bands was observed, except that most of the minor peptides were eliminated in the final semi-purified haemolysin preparation. DEAE-Sephacel chromatography gave an increase in specific haemolytic activity of about 85 -fold and a recovery of $13 \%$. However, this haemolysin fraction contained the major $36 \mathrm{kDa}$ peptide and there were still a few different peptide bands on the SDS-PAGE (Fig. 1, lane 4). The mobility in the gel of these peptides was not influenced by the presence of 2-mercaptoethanol in the solubilizing buffer. We used this semi-purified haemolysin fraction for further experiments.

Characterization of the semi-purified haemolysin. This haemolysin was active against erythrocytes from nine animal species: it was most active against sheep and mouse erythrocytes, and less active against chicken, rabbit and human erythrocytes. Heating at $56^{\circ} \mathrm{C}$ for $30 \mathrm{~min}$ inactivated this haemolysin. The semi-purified haemolysin still possessed lethal activity in mice (MLD $100 \mu \mathrm{g}$ protein per mouse). When mice were injected intravenously with 1 MLD of haemolysin, none survived for over $6 \mathrm{~h}$. The haematocrit value at $5 \mathrm{~h}$ showed a prominent haemoconcentration.

Production of MAbs against haemolysin. Seven clones produced antibodies inhibitory to the haemolysin (Table 1). All were of the IgG2b subclass with lambda light chains. Clone 6F8D had the highest inhibitory titre (Table 1) and was used for further experiments.

Protective effect of MAb $6 F 8 D$ against mouse lethal challenge with the haemolysin preparation. This was examined either by in vitro neutralization or by passive transfer of MAb to mice. When the haemolysin at a dose of 1 MLD was incubated with diluted ( 1 in 10,1 in 5 or 1 in 2) MAb 6F8D, its lethal effect in mice was neutralized. MAb 6F8D diluted 1 in 5 or 1 in 2 also neutralized 2 MLD of haemolysin, but a 1 in 10 dilution only incompletely neutralized this amount of haemolysin (data not shown). In passive transfer experiments, the twofold-diluted MAb 6F8D sample conferred complete protection against challenge with 1 MLD of haemolysin and the protective effect of the MAb diminished with dilution. Similar patterns were observed even after challenge with 3 MLD of haemolysin (data not shown). Thus, we concluded that MAb 6 F8D protected mice against the lethal activity exerted by the haemolysin.

Immunoblotting analysis. Reactivity of the MAbs to the peptides of the semi-purified haemolysin preparations was tested by immunoblotting analysis; a representative result with 


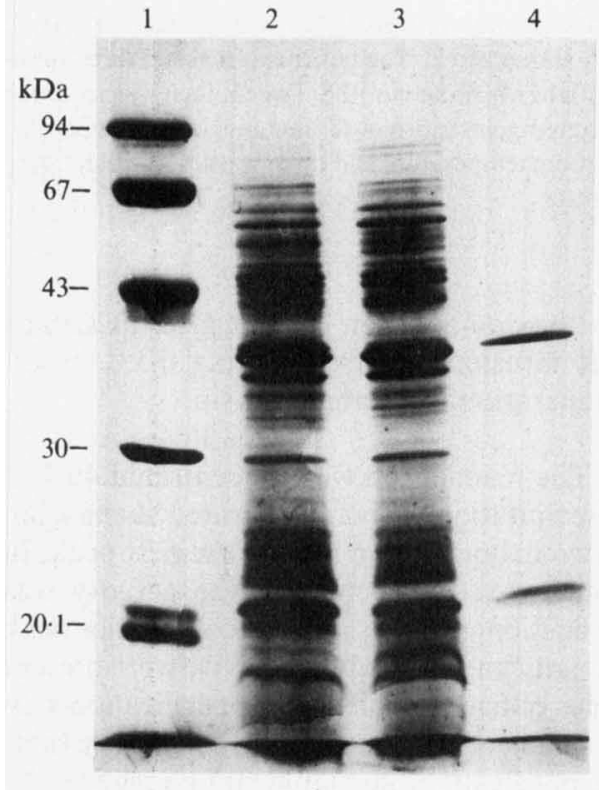

Fig. 1

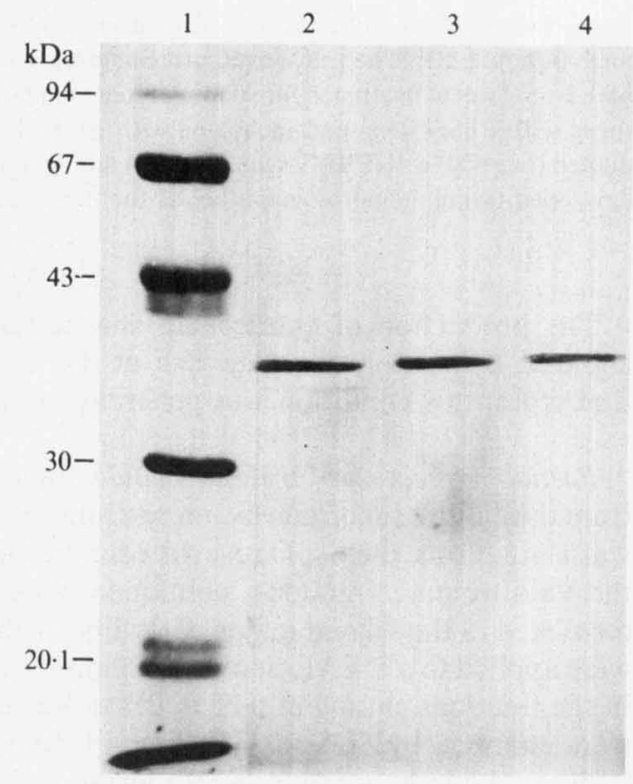

Fig. 2

Fig. 1. SDS-PAGE of the extracellular haemolysin preparations. Samples were denatured under reducing conditions (2-mercaptoethanol in the solubilizing buffer). Lanes: 1, molecular mass markers (Pharmacia); 2, ammonium sulphate precipitate (100 $\mu$ g protein); 3, peak 2 of the Sepharose 4B gel filtration concentrate (100 $\mu \mathrm{g}$ protein); 4 , DEAE-Sephacel eluate concentrate $(80 \mu \mathrm{g}$ protein). The gel was stained with Coomassie brilliant blue R-250.

Fig. 2. Immunoblot analysis: reactivity of $\mathrm{MAb} 6 \mathrm{~F} 8 \mathrm{D}$ was examined against haemolysin at different stages of purification. The haemolysin preparations were separated by SDS-PAGE and electrophoretically transferred to nitrocellulose paper. The paper strip was then incubated for $90 \mathrm{~min}$ with a 1 in 100 dilution of MAb 6F8D ascites. Lanes: 1, molecular mass markers that were transferred and stained with Amido black ; 2-4, as in Fig. 1; blots were probed with horseradish peroxidase-conjugated goat anti-mouse immunoglobulins $\mathrm{G}$.

Table 1. Comparative ELISA reactivity and haemolytic inhibition titre of $M A b s$

$\begin{array}{lcc}\text { MAb* }^{*} & \begin{array}{c}\text { ELISA reactivity } \\ \left(A_{490}\right) \dagger\end{array} & \begin{array}{c}\text { Haemolytic inhibition } \\ \text { titre }+\end{array} \\ \text { 2F4H } & 0.398 \pm 0.115 & 8 \\ \text { 2F6A } & 0.332 \pm 0.052 & - \\ \text { 4G7G } & 0.498 \pm 0.076 & 8 \\ \text { 5D10A } & 0.352 \pm 0.106 & 2 \\ \text { 6F8D } & 0.405 \pm 0.096 & 128 \\ \text { 10D4C } & 0.300 \pm 0.108 & 4 \\ \text { 11F11D } & 0.310 \pm 0.080 & 16\end{array}$

* All the MAbs were of the IgG2b-lambda subtype.

+ The values represent means \pm standard error of at least four experiments.

$\ddagger$ Reciprocal of the highest dilution of MAb that blocked complete haemolysis. Control P3U1-induced normal ascites fluid had no inhibitory effect. -, Not determined.

the MAb 6F8D is shown in Fig. 2. Only one peptide on SDS-PAGE of the crude haemolysin reacted with $6 \mathrm{~F} 8 \mathrm{D}$. MAbs other than $6 \mathrm{~F} 8 \mathrm{D}$ also reacted with the same band of protein (data not shown). These data suggest that the haemolysin is identical to the lethal product in the culture supernate of $V$. vulnificus and that the major antigenic epitope on the haemolysin was present in the $36 \mathrm{kDa}$ peptide. 


\section{DISCUSSION}

In the present study, several MAbs were raised against semi-purified extracellular products of $V$. vulnificus. All the MAbs studied clearly recognized a single peptide in the semi-purified extracellular products, as revealed by immunoblotting. One representative MAb, 6F8D, completely neutralized the haemolytic activity of the semi-purified toxin. MAb 6F8D also neutralized the lethal activity observed in mice. As an MAb is an antibody of defined specificity to a single epitope, these observations strongly suggest that the haemolysin is identical to the lethal toxin present in the culture supernate of $V$. vulnificus.

This observation supports evidence obtained by Gray \& Kreger (1985) that the purified cytolysin preparation has a haemolytic activity as well as lethal activity for mice, cytotoxicity for CHO cells, and vascular permeabilizing activity. Their cytolysin had a molecular mass of about $56 \mathrm{kDa}$ (estimated by SDS-PAGE and by amino acid analysis) and the peptide patterns of cytolysin preparations in SDS-PAGE were influenced by the conditions used to denature the preparations. The haemolysin recognized by our MAbs has a molecular mass of about $36 \mathrm{kDa}$ (estimated by SDS-PAGE and by subsequent immunoblotting) and the peptide bands in SDSPAGE were not influenced by denaturation, with or without 2-mercaptoethanol. However, similarities between their $56 \mathrm{kDa}$ cytolysin and our $36 \mathrm{kDa}$ haemolysin include the following: (1) optimal conditions for haemolysin production were practically identical to those for cytolysin production reported by Tison \& Kelly $(1984 a)$; (2) the purified cytolysin reported by Gray \& Kreger (1985) was strongly hydrophobic and our haemolysin resembled their cytolysin with regard to its behaviour during hydrophobic chromatography (i.e. eluting in the presence of $50 \%$ ethylene glycol: data not shown); (3) the pattern of sensitivity of erythrocytes from nine animal species to our haemolysin and the inactivation of the haemolysin by heating $\left(56^{\circ} \mathrm{C}, 30 \mathrm{~min}\right)$ were the same as observed by Gray \& Kreger (1985).

These data suggest that these haemolytic materials produced by $V$. vulnificus are similar biologically active products but are heterogeneous, at least in molecular mass. There are at least three possible explanations for this hypothesis. One possibility is the production of two different haemolysins by a single strain, and a second is the production of different haemolysins from one strain to another. It might be possible for one strain of $V$. vulnificus to produce different kinds of haemolytic substances. $V$. parahaemolyticus produces various enzymes causing haemolysis, namely phospholipase $\mathrm{A}$, lysophospholipase, glycerophosphorylcholine diesterase, and two kinds of direct haemolysins, one of which is heat-stable and the other heat-labile (Yanagase $e t$ al., 1970). In the present experiments, we did not study the enzymic activity of the $36 \mathrm{kDa}$ haemolysin. A third possibility is that the $56 \mathrm{kDa}$ cytolysin is cleaved by partial proteolysis to form the $36 \mathrm{kDa}$ haemolysin. In this case, the epitope on the $56 \mathrm{kDa}$ molecule might be inaccessible for our MAb because of the conformation of the molecule. Further study is required to prove that $V$. vulnificus has two different types of haemolysins. Immunoblotting analyses using various supernates produced by different $V$. vulnificus strains and our established MAbs are now under way.

We thank Tetsuhiro Moriya for excellent technical advice and M. Ohara for comments on the manuscript.

\section{REFERENCES}

Amako, K., OKada, K. \& Miake, S. (1984). Evidence for the presence of a capsule in Vibrio vulnificus. Journal of General Microbiology 130, 2741-2743.

Blake, P. A., Weaver, R. E. \& Hollis, D. G. (1980). Diseases of humans (other than cholera) caused by vibrios. Annual Review of Microbiology 34, 341-367.

Bowdre, J. H., Poole, M. D. \& Oliver, J. D. (1981). Edema and hemoconcentration in mice experimentally infected with Vibrio vulnificus. Infection and Immunity 32, 1193-1199.
FARMER, J. J., III (1979). Vibrio ('Beneckea') vulnificus, the bacterium associated with sepsis, septicaemia and the sea. Lancet ii, 903.

Frank, D. W. \& PARKer, C. D. (1984). Interaction of monoclonal antibodies with pertussis toxin and its subunits. Infection and Immunity 46, 195-201.

Gray, L. D. \& Kreger, A. S. (1985). Purification and characterization of an extracellular cytolysin produced by Vibrio vulnificus. Infection and Immunity 48, 62-72. 
GRAY, L. D. \& KREger, A. S. (1986). Detection of antiVibrio vulnificus cytolysin antibodies in sera from mice and a human surviving $V$. vulnificus disease. Infection and Immunity 51, 964-965.

Harn, D. A., Mitsuyama, M. \& David, J. R. (1984). Schistosoma mansoni anti-egg monoclonal antibodies protect against cercarial challenge in vitro. Journal of Experimental Medicine 159, 1371-1387.

Hollis, D. G., Weaver, R. E., Baker, C. N. \& THORNSBERRY, C. (1976). Halophilic Vibrio species isolated from blood cultures. Journal of Clinical Microbiology 3, 425-431.

Honda, T., Taga, S., Hashibuan, M. A., Takeda, Y. \& MiWATANI, T. (1976). Identification of lethal toxin with the thermostable direct hemolysin produced by Vibrio parahaemolyticus, and some physicochemical properties of the purified toxin. Infection and Immunity 3, 133-139.

Kamata, Y., Kozaki, S., Nagai, T. \& Sakaguchi, G. (1985). Production of monoclonal antibodies against Clostridium botulinum type E derivative toxin. FEMS Microbiology Letters 26, 305-309.

Kothary, M. H. \& Kreger, A. S. (1985). Production and partial characterization of elastolytic protease of Vibrio vulnificus. Infection and Immunity 50, 534-540.

KREGER, A. \& LockWOOD, D. (1981). Detection of extracellular toxin(s) produced by Vibrio vulnificus. Infection and Immunity 33, 583-590.

Kreger, A. S., Gray, L. D. \& Testa, J. (1984). Protection of mice against Vibrio vulnificus disease by vaccination with surface antigen preparations and anti-surface antigen antisera. Infection and Immunity 45, 537-543.

LAEMMLI, U. K. (1970). Cleavage of structural proteins during the assembly of the head of bacteriophage T4. Nature, London 227, 680-685.

POOI E, M. D. \& Oliver, J. D. (1978). Experimental pathogenicity and mortality in ligated ileal loop studies of the newly reported halophilic lactosepositive Vibrio sp. Infection and Immunity 20, 126129.

Remmers, E. F., Colwell, R. R. \& Goldby, R. A. (1982). Production and characterization of mono- clonal antibodies to cholera toxin. Infection and Immunity 37, 70-76.

Sheppard, A. J., Cussell, D. \& Hughes, M. (1984). Production and characterization of monoclonal antibodies to tetanus toxin. Infection and Immunity 43, 710-714.

Shinoda, S., Miyoshi, S., Yamanaka, H. \& NakaHARA, N. M. (1985). Some properties of Vibrio vulnificus hemolysin. Microbiology and Immunology 29, 583-590.

Simpson, L. M. \& Oliver, J. D. (1983). Siderophore production by Vibrio vulnificus. Infection and Immunity 41, 644-649.

SMITH, G. C. \& Merkel, J. R. (1982). Collagenolytic activity of Vibrio vulnificus: potential contribution to its invasiveness. Infection and Immunity 35, 11551156.

Testa, J., Daniel, L. W. \& Kreger, A. S. (1984). Extracellular phospholipase A2 and lysophospholipase produced by Vibrio vulnificus. Infection and Immunity 45, 458-463.

TISON, D. L. \& KeLLY, M. T. (1984a). Factors affecting hemolysin production by Vibrio vulnificus. Current Microbiology 10, 181-184.

TISON, D. L. \& KeLLY, M. T. (1984b). Vibrio species of medical importance. Diagnostic Microbiological Infectious Disease 2, 263-276.

Towbin, H., Staehelin, T. \& Gordon, J. (1979). Electrophoretic transfer of proteins from polyacrylamide gels to nitrocellulose sheets: procedure and some applications. Proceedings of the National Academy of Sciences of the United States of America 79, 4350-4354.

Yanagase, Y., Inoue, K., Ozaki, M., Ochi, T., amano, T. \& Chazono, M. (1970). Hemolysins and related enzymes of Vibrio parahaemolyticus. 1. Identification and partial purification of enzymes. Biken Journal 13, 77-92.

Yoshida, S., Ogawa, M. \& Mizuguchi, Y. (1985). Relation of capsule materials and colony opacity to virulence of Vibrio vulnificus. Infection and Immunity 47, 446-451. 